\title{
Living with the Ancient Romans: Past and Present in Eighteenth-Century Encounters with Herculaneum and Pompeii
}

\author{
Charlotte Roberts
}

\begin{abstract}
The eighteenth-century "discovery" of the buried cities of Herculaneum and Pompeii revolutionized the way in which individuals thought about their relationship with the ancient world. The accounts of British visitors between 1738 and the end of the century reflect a new historical sensibility, one predicated upon the extraordinary proximity between present and past that these sites seemed to promise. In this essay, Charlotte Roberts examines the work of four individuals-Camillo Paderni, Johann Joachim Winckelmann, Johann Wolfgang von Goethe, and Sir William Hamilton-all of whom used the prevailing vocabulary associated with Herculaneum and Pompeii in order to articulate individual and in several cases innovative arguments on subjects as diverse as the validity of Neapolitan Bourbon rule, the ideal of Greek art, and the history of the earth. Their ideas indicate that these excavations, in a small but significant way, helped to shape a diverse range of eighteenth-century thought. KEY WORDS: eighteenthcentury attitudes toward the ancient world; archaeology and natural history of Naples; classical and neoclassical aesthetics; national treasures and absolute monarchy; history of everyday life; Charles of Bourbon
\end{abstract}

One hates writing descriptions that are to be found in every book of travels; but we have seen something today that I am sure you never read of, and perhaps never heard of. Have you heard of the subterraneous town? a whole Roman town with all its edifices remaining underground? ${ }^{1}$

— THE "DISCOVERY," IN 1738, of the ancient Roman city of Herculaneum, lost to the world since the eruption of Vesuvius in the year $79 \mathrm{CE}$, revolutionized the way in which eighteenth-century individuals envisaged their relationship with the past. The

1. Horace Walpole to Richard West, Tuesday, June 14, 1740, The Yale Edition of Horace Walpole's Correspondence, ed. W. S. Lewis, 48 vols. (New Haven, Conn., 1937-83), 13:222.

Pp. 61-85. (C)2015 by Henry E. Huntington Library and Art Gallery. ISSN 0018-7895 | E-ISSN 1544-399x. All rights reserved. For permission to photocopy or reproduce article content, consult the University of California Press Rights and Permissions website, http://www.ucpressjournals.com/reprintInfo.asp. DOI: 10.1525/hlq.2015.78.1.61. 
settlement that was unearthed was desirably ancient: an early-imperial remnant untainted by modern interference and holding out the tantalizing possibility of hidden reserves of Greek art. At the same time the city was an object of novelty and wonder: a hitherto unthought-of phenomenon that allowed visitors-especially those, like Horace Walpole, treading the well-worn path of the Grand Tourist-to experience and say something new, unhampered by the centuries of familiarity that weighted all encounters with the monuments of Rome. Naples had traditionally offered "wonders" to European visitors, with the natural phenomena of the volcanic landscape allowing tourists to experience geographical extremes while surrounded by seemingly preternatural lushness and fertility. ${ }^{2}$ From the outset of the official Bourbon excavations at Herculaneum, the area also offered the possibility of an encounter with the ancient world that might not only rival Rome but even compensate for some of the shortcomings and disappointments experienced by visitors to that ancient city. If Rome threatened its tourists with a homogeneity of experience and response, Herculaneum and Pompeii offered novelty and difference. While Rome demanded recognitionwhich could slide quickly into confusion and estrangement when the scenes familiar from classical literature and history proved impossible confidently to identify-the Bourbon excavations allowed all visitors to engage in a fantasy of discovery. 3

The idea of an entire Roman society lying dormant beneath layers of volcanic debris awaiting its rediscovery by an enlightened and appreciative world is all the more striking because it is a fiction. The locations of Pompeii and Herculaneum were preserved in local knowledge during the intervening centuries, and casual excavation in search of valuable materials and artifacts occurred throughout the ancient and medieval periods. The myth of sudden recovery was in part a convenient fiction promoted by the Bourbon court, the dominant influence behind the later, state-controlled excavation project. ${ }^{4}$ However, the prevalence and tenacity of this fantasy indicate that it fulfilled a widely experienced desire to imagine a strong, unmediated, and privileged connection between these cities and the contemporary world. Thomas Martyn describes the artifacts of these sites as "reserved in the bowels of the earth, safe from the ravages of time and barbarians, during seventeen centuries," employing a language of destined encounter that is characteristic of visitors as well as the people at the heart of the official excavations. 5 By interpreting Herculaneum and Pompeii as pristine artifacts, unmolested and unrecognized for almost 1,700 years, eighteenth-century indi-

2. Chloe Chard, Pleasure and Guilt on the Grand Tour: Travel Writing and Imaginative Geography, 1600-1830 (Manchester, 1999).

3. Rosemary Sweet, “The Changing View of Rome in the Long Eighteenth Century," Journal for Eighteenth-Century Studies 33, no. 2 (2010): 145-64 at 148-50. Journals and letters written by British tourists show that this sense of being "first on the scene" was a common reaction to Herculaneum and Pompeii even after decades of official excavation. See [Lady Anna Miller], Letters from Italy, describing the Manners, Customs, Antiquities, Paintings, \&c. of that Country, in the Years 1770 and 1771, 3 vols.

(Dublin, 1776), 2:218.

4. Andrew Wallace-Hadrill, Herculaneum: Past and Future (London, 2011), 47-48.

5. Thomas Martyn, The Gentleman's Guide in his Tour through Italy. With a Correct Map, and Directions for Travelling in that Country (London, 1787), 284, my emphasis. 
viduals were able to imagine themselves as privileged communicators with an ancient past, of which they were the most deserving heirs.

The archetypical Grand Tourist of the seventeenth or early eighteenth century claimed to be the heir of Roman virtù through his dedication to political liberty and appreciation for the ideals of ancient art. Although Herculaneum and Pompeii supported the idea of privileged inheritance, the excavations also played an important role in challenging the standards associated with the Grand Tourist, especially as the century progressed. The shifting demographic of visitors to Italy over the course of the eighteenth century challenged the ideological monopoly enjoyed by the British, aristocratic male over engagement with the classical past. Herculaneum and Pompeii offered a new kind of visitor a new way to identify with the ancient world, predicated less upon shared values of political liberty and classical virtue than upon a common humanity. It is revealing to note how many visitors to these sites, antiquarians as well as amateurs, devote as much or even more attention to describing the ordinary and everyday objects uncovered by the excavators as they do to illustrating the paintings and statues assembled by the king in his official museum. Bread, cloth, ink, wine, as well as lamps, furniture, and kitchen equipment were the objects that inspired visitors such as Hester Lynch Piozzi to reflect on the divisions between the public and the domestic, the elite and the common:

Royalty demolished, and Empire destroyed;-Power unlimited once, now changed to a childish display of empty splendour; and Riches heaped up as the Scripture says, without knowing who was to gather them are the Images with which Rome impresses one's Imagination-but here the Business comes closer to our own Bosom. The Shopkeepers killed by a sudden Burst of Fire from the neighbouring Mountain-Soldiers stifled in the Guard Room, and Babies in the Cradle - these are the Things to strike [and] terrify those who examine them: [ ... ] for we cannot all be Kings and Heroes; but we are all Men and Women. ${ }^{6}$

The transition from the elite and public world of political history and heroic action, which encourages moral reflection, to the social history of ordinary individuals, which encourages sympathetic engagement, is one that many scholars have traced through the decades of the eighteenth century. 7 It is remarkable that Piozzi identifies the same development as one that occurs in space rather than in time. Instead of contrasting an earlier historiography of kings and heroes with a later one of ordinary men and women, Piozzi contrasts the imposing grandeur of Rome with the intimate and pathetic details of Herculaneum and Pompeii, so that the latter cities exemplify an unprecedented intensity and intimacy of engagement with the past.

6. Piozzi to Samuel Lysons, Naples, December 31, 1785, The Piozzi Letters: Correspondence of Hester Lynch Piozzi, 1784-1821, ed. Lillian D. Bloom, 6 vols. (Newark, 1989-2002), 1:175-77 at 176-77.

7. See, for example, Mark Salber Phillips, Society and Sentiment: Genres of Historical Writing in Britain, 1740-1820 (Princeton, N.J., 2000). 
Items of everyday use or consumption inspire feelings of sympathetic closeness when modern observers reflect on the fate of their original owners. This is only one of the ways, however, in which the accouterments of everyday life seem to guarantee the proximity of present and past. The extraordinary preservation of objects, especially of obviously perishable substances such as food or wine, caught the imagination of foreign visitors. ${ }^{8}$ The apparent freshness of these materials, which were seemingly exempt from the usual processes of corruption and decay, invited visitors to think of the excavations as less an investigation into a society already dead and ossified than a reanimation of a community that for centuries had been preserved in a kind of stasis, removed from the influence of passing time. As early as 1747 , before the discovery of Pompeii, Francesco Scipione Maffei imagines that if Herculaneum were completely excavated, "the lifeless city would be reborn."9 As late as 1797 Mariana Starke writes that to "visit [Pompeii ... ] is absolutely to live with the ancient Romans."10 The perception of these sites as places that straddle the divide between present and past, or living and dead, contributes to a peculiar understanding of time that is highly characteristic of the Neapolitan environment. In "Some Thoughts on Time in Naples," Peter Gunn writes:

It does appear curious that in Naples, to a degree perhaps not experienced in other cities, one has a peculiarly heightened awareness of the present moment, a sense of sensuous immediacy, the enveloping, luminous present, the here and now. It is to instants, vivid points, of time that I am referring, not so much to duration; to the momentary present, apprehended in all its fullness, or to those echoes of such a present, visions of such other once present instants, now in the past. ${ }^{11}$

It was to just such a vivid and immediate present, now in the past, that the excavations at Herculaneum and Pompeii provided imaginative access. "[T] he Bread left baked, the Meat put upon the dishes, the Wine petrified in the Decanters, the impression of a Fool in the Act of escaping": these are the images that speak to Piozzi of a disturbingly arrested here and now, forever frozen in time by the overwhelming operations of nature. ${ }^{12}$ This sense of the past as a present moment, preserved for centuries before it releases its uncanny echo into the contemporary world, is a geographically particular

8. Lady Anna Miller remarks that the wine still retains its rich scent, Letters from Italy, 187-88.

9. Tre lettere del Signor Marchese Scipione Maffei (Verona, 1748). Quoted in translation in Christopher Charles Parslow, Rediscovering Antiquity: Karl Weber and the Excavation of Herculaneum, Pompeii, and Stabiae (Cambridge, 1995), 244.

10. Mariana Starke, Letters from Italy, between the Years 1792 and 1798, containing a View of the Revolutions of that Country, 2 vols. (London, 1800), 2:107.

11. Peter Gunn, "Some Thoughts on Time in Naples," in Oxford, China and Italy: Writings in Honour of Sir Harold Action on his Eightieth Birthday, ed. Edward Chaney and Neil Ritchie (Florence, 1984), 124-32 at 124.

12. Piozzi to Samuel Lysons, December 31, 1785, Piozzi Letters, 1:176. 
conception that emerges in emphatic contrast to the experience of most eighteenthcentury visitors to the monuments of ancient Rome.

Robert Gray's letters from Italy, written in 1791-92, record the confusion felt by many eighteenth-century travelers at their first encounter with the remnants of that ancient city:

In the spirit of classical enthusiasm which is kindled at the sight of Rome, many would, perhaps, enquire first for the capitol, the forum, the colissaeum or the triumphal arches. But the monuments of antiquity we know to be almost dilapidated and half concealed amidst modern buildings, and half buried in their own ruins. [...]

[... It is vain to look for any features of Pagan or Christian Rome separately: they are strangely blended and incorporated together. It is sometimes difficult to ascertain the works of ancient and modern times, and almost impossible to discriminate between the characters of ancient and modern superstition. ${ }^{13}$

The confusion, prompted most particularly by the decay of ancient Roman art and buildings over time and the indiscriminate mixing of ancient and modern (two things to which Herculaneum and Pompeii were not subject), is remedied by the imposition of a narrative of historical process, in which the confusion of contemporary Rome is made the culmination of an intellectually, perhaps even morally, satisfying account of the centuries since its triumph:

The common spectator, who glances over the vestiges of Rome merely as objects of sight, is soon wearied; but the intelligent traveller, who dwells with improving meditation on the changes which the city has sustained, and on the moral causes that have effected them, feels considerable satisfaction in this wonderful place, and finds every object pregnant with instruction. The Colissaeum, striking as a beautiful ruin, does not sufficiently arrest our attention, unless we recollect not only the savage purposes to which it was generally applied, but that the altars, raised within its circumference, are consecrated to saints martyred there for a religion now triumphant. ${ }^{14}$

A historical narrative of cause and effect is necessary in order to protect the tourist from confusion, boredom, and disgust in the face of this hybrid monument of ancient, decadent splendor and modern superstition. Simple observation and aesthetic

13. Robert Gray, Letters during the Course of a Tour through Germany, Switzerland and Italy, in the Years 1791 and 1792 (London, 1794), 351, 354.

14. Ibid., 365 . 
enjoyment of a ruin such as the Colosseum do not allow the viewer to imaginatively access the past it represents.

Gray's narrative of imperial decline and Catholic triumph, so necessary for him to a proper understanding of Rome, is not matched by any equivalent narrative governing his response to the ruins of Pompeii. There the immediate apprehension of a seemingly chaotic mixture of buildings and objects is enough to give instantaneous access to the ancient past. The mélange of the domestic and the public, the intellectual and the superstitious, and of high and low life heightens the sensuous immediacy of an encounter with these ancient settlements:

At our first slight descent at the entrance, we see the soldier's quarters, with the names of some ancient Romans, inscribed above seventeen centuries ago, on the walls; the plat-form and proscenia of two theatres; some rooms of a private house, with a human skull that once was animated with the features of Roman genius; the impression of a foot sunk in yielding lava; the perfect form of the temple of Isis, built of stuccoed brick; its columns, its altars; the caenabulum of the priests, in which the bones of some fish were found; the slaughter-house with the still-existing ring to which the generous and struggling victim was tied, and the canal by which the blood was conducted away. ${ }^{15}$

Gray's asyndetic syntax presents a vision of Pompeii as a series of quasi-photographic stills of the early imperial past, isolated from the dynamics of process and change that govern traditional historiographical explication. The effect of such a conception is to heighten even further the impression of closeness between past and present invoked by these buried cities, which rather than being separated from the contemporary world by a measurable period of years and centuries are nearly contiguous with it in the moment of imaginative reanimation.

Eighteenth-century individuals who encountered the ancient cities of Pompeii and Herculaneum, whether as tourists, antiquarians, artists, diplomats, proprietors, or politicians, were overwhelmingly inspired by the vivid and unmediated proximity between past and present that these cities offered. This idea takes many forms in the texts these individuals left behind: from assertions of the privileged, even providential, nature of "discovery" to empathetic identification with these settlements' lost citizens. Although I have chosen to focus on the reports of British visitors, scholars who have studied the accounts of other European visitors have noted similar patterns of thinking, and this sense of proximity is also found in the publications of those who, while they helped to shape British thinking on Herculaneum and Pompeii, were themselves outside of or peripheral to British culture. ${ }^{16}$ Nor are texts the only media in which this concept is articulated. Eighteenth-century art, fashion, and domestic furnishing were

15. Ibid., 410.

16. Chantal Grell, Herculanum et Pompéi dans les récits des voyageurs français du XVIIle siècle, Mémoires et documents sur Rome et l'Italie méridionale 2 (Naples, 1982). 
all inspired by the idea of Herculaneum and Pompeii, even if there has been some critical dissent regarding the specific influence of the objects and designs unearthed during the excavations. ${ }^{17}$ The dissemination of aesthetic details was subject to vigorous state control and made only slow progress through the distribution of diplomatic gifts and state-sanctioned publications. Nevertheless there is evidence for a plethora of unofficial objects and performances inspired by the motif of the contemporary antique popularized by these excavations, if not by the specific details of the Herculanean and Pompeian artifacts..$^{18}$

The excavations carried out in the environs of Naples during the eighteenth century contributed to a burgeoning interest in the history of everyday life-a contribution that presages Pompeii's twenty-first-century role as a unique source for social and cultural histories of the ancient world. At the same time, the historical thinking inspired by Herculaneum and Pompeii is itself a culturally and socially illustrative phenomenon, through which men and women of different nationalities, ages, social classes, and historical periods arrive at innovative apprehensions of the ancient past. It would be wrong, however, to reduce the complex responsiveness of those who encountered the buried cities to a homogenous and depersonalized collective reaction, divorced both from political, social, and economic realities, and from individual thought. Those who visited Herculaneum and Pompeii over the course of the eighteenth century helped to shape and were in turn shaped by a new historical sensibility and attitude concerning the ancient world. This process leads to many points of comparison between observers otherwise separated by time, nationality, class, or gender, but it also provided opportunities for individuals to appropriate a shared cultural vocabulary in order to articulate unique, and sometimes subversive, arguments and ideas. In the remainder of this essay I will examine the work of four individuals - the painter and curator of the Herculaneum Museum, Camillo Paderni; Johann Joachim Winckelmann; Johann Wolfgang von Goethe; and Sir William Hamilton—all of whom used the prevailing historical sensibilities associated with Herculaneum and Pompeii in order to shape and articulate complex and personal intellectual positions. These individual appropriations show how, for some of those who engaged with Herculaneum and Pompeii, the importance of these sites extended far beyond any neoclassical revival, helping to shape political culture, the theory of art, and even the history of the world.

17. Harold Acton argues for the specific influence of the art and antiquities of these excavations, spread by the publication of Le Antichità di Ercolano, in The Bourbons of Naples (1734-1825) (London, 1956), 89. Agnes Allroggen-Bedel downplays the influence of this official publication, arguing instead for "spiritual influence" sparked by a general interest in the excavations. "Gli scavi di Ercolano nella politica culturale dei Borboni," in Ercolano 1738-1988: 250 anni di ricerca archeologica (Rome, 1993), 35-39 at 37 .

18. Lady Anne Miller writes to her friend from Naples that she has "had a comb made for my chignion incrusted with gold, to imitate an Etruscan border, copied from an antique vase," Letters from Italy, 2:174. Emma Hamilton's famous attitudes, which may have been inspired in part by wall paintings discovered at Herculaneum, helped to disperse a neoclassical aesthetic throughout Europe. See Tina Najbjerg, "From Art to Archaeology: Recontextualizing the Images from the Porticus of Herculaneum," in Antiquity Recovered, 59-72 at 66. 


\section{Camillo Paderni and the Politics of Excavation}

In 1740 the Philosophical Transactions of the Royal Society published extracts from two letters sent by Camillo Paderni, a painter in Rome, to his friend Allan Ramsay concerning "some antient Statues, Pictures, and other Curiosities, found in a subterraneous Town, lately discovered near Naples." This early account of Herculaneum contains many features that were later to become characteristic of descriptions of that city. The vividness of classical antiquity is conveyed by the description of paintings "as fresh as if they had been done a Month ago," which can only be properly compared with the masterpieces of modern art. Paderni also attacks what he sees as the limitations of the Bourbon-directed excavations: the reliance on unskilled labor, the practice of backfilling areas that had already been explored, the extraction of paintings without due regard to their original situation, and the reinterment of works of art not deemed worthy of extraction. Paderni is dismissive of those currently overseeing the excavations ("those Men they call Intendants") as well as of the king of Naples and his antiquarian pretensions. At the same time he claims an intellectual prerogative to comment on the finds and to interfere in their discovery. So great is his personal connection to the ancient city that the ignorance of the superintendents makes him "suffer in a very sensible Manner; so that every Day appear[s] a Month" until he is able to deliver his own recommendations to the directors. ${ }^{19}$

Paderni's condemnation of the Bourbon excavations is just one example in a culture of criticism and invective stretching from the late 1730 s to the present day. The methods and motivations of the Neapolitan court are even now frequently disparaged, with blame focusing on the lack of historical appreciation governing excavations that were carried out primarily in pursuit of art objects for the king's palace and museum. Although several scholars have acknowledged the political intentions governing the excavations conducted by the Bourbon court, only relatively few seem willing to take these seriously as valid motives. ${ }^{20}$ Where political utility clashed with the desire to preserve, study, or even enjoy these remnants of the past, decisions were sometimes made that have been wrongly interpreted as the effects of ignorance or callousness. In 1740 Camillo Paderni wrote to his friend of his "great Concern for those fine Things in a perishing Condition" and bemoaning the loss of small, incidental paintings through the excavation of large pieces and the practice of back-filling. From the 1750 os onward, the same Camillo Paderni personally oversaw a policy that demanded the deliberate destruction of all paintings that were not significant enough to remove to the Portici Museum, in order to prevent their distribution outside the Bourbon collections. ${ }^{21}$ It is

19. "Extracts of Two Letters from Sigr Camillo Paderni at Rome, to Mr. Allan Ramsay, Painter, in Covent-Garden, concerning some antient Statues, Pictures, and other Curiosities, found in a subterraneous Town, lately discovered near Naples. Translated from the Italian by Mr. Ramsay, and sent by him to Mr. Ward, F.R.S. Prof. Rhet. Gresh.", Philosophical Transactions 41 (1740): 484-89.

20. Those who have written about the political motives of the excavations, from a variety of perspectives, include Alden R. Gordon, "Subverting the Secret of Herculaneum: Archaeological Espionage in the Kingdom of Naples," in Antiquity Recovered, 37-57; Wallace-Hadrill, Herculaneum, 40-63; and Allroggen-Bedel, "Gli scavi di Ercolano," 35-39.

21. For a discussion of this policy, see Parslow, Rediscovering Antiquity, 206-8. 
not that Paderni surrendered his belief in the historical importance of these works over a single decade-his period of control over the excavations is characterized by an almost obsessive need to personally document and assess the discoveries-nor is it likely that he lost all his emotional commitment to these spectacular remains between the ages of twenty and thirty. ${ }^{22}$ Much more probable is that he altered his professed attitudes over time in response to the practical pressures of his immediate situation. In 1740, as a twenty-year-old painter in Rome keen to maintain his links with a European community of artists and connoisseurs, he highlights his own good taste and antiquarian credentials by celebrating the discoveries and critiquing their excavation. In the 1750 his letters to his friends in England reflect his new preoccupations as an employee of the Bourbon court and subsequently as curator of the king's museum at Portici.

In 1734 Charles of Bourbon became king of Naples, ending the War of the Polish Succession and two decades of Austrian rule. His immediate priority was to establish the validity of his new, independent monarchy (after two centuries of viceroys), both with his subjects and on the European stage. The Southern Italian kingdom he inherited was still markedly feudal, with a powerful, independent nobility. His own efforts and those of his advisors were directed toward establishing an absolute monarchy that would radiate power and prestige from a centralized royal court. ${ }^{23}$ The excavations at Herculaneum and Pompeii helped the Bourbon monarchy to fulfill these aims by establishing Charles as a virtuoso monarch and by providing cultural capital valuable at both a local and international level. The collecting of antiquities had traditionally been a source of private power and prestige in Southern Italy, and by preventing the dissemination of even the smallest artifact from Herculaneum and Pompeii among his subjects, Charles was able to signal his own unassailable power in his new kingdom. ${ }^{24}$ By jealously guarding the cities' objects and designs from European visitors, who were not allowed to sketch or make notes on site or in the museum, the Bourbon excavators were able to reserve the intellectual and diplomatic value of the finds, realized by carefully distributing publications, reproductions, and fashionable gifts inspired by the discoveries to the heads of Europe. This diplomatic value was in part offset by the illfeeling of many European visitors, especially in the early decades of the excavations at Herculaneum, who felt themselves snubbed by the restrictions placed on their engagement with the discoveries. This does not mean, however, that the Bourbon excavations failed on their own terms. Although it was important that Charles signal his prestige to neighboring monarchs, especially within Italy, the absolutism he hoped to cultivate was in many ways incompatible with a strongly Eurocentric outlook. ${ }^{25}$ Disparagement

22. Mariette de Vos, “Camillo Paderni, la tradizione antiquaria romana e i collezionisti inglesi," in Ercolano 1738-1988, 99-116 at 107.

23. Naples in the Eighteenth Century: The Birth and Death of a Nation State, ed. Girolamo Imbruglia (Cambridge, 200o), esp. chaps. 1 and 2.

24. Claire Lyons, "The Neapolitan Context of Hamilton's Antiquities Collection," Journal of the History of Collections 9, no. 2 (1997): 229-39.

25. It was to Europe - to France and Britain — that Neapolitan nobles and intellectuals looked for examples of political opposition to absolute monarchy and mixed constitutions. Maria Grazia Maiorini, "The Capital and the Provinces," in Naples in the Eighteenth Century, ed. Imbruglia, 4-21 at 15. 
from antiquarians and intellectuals both inside and outside the Kingdom of Naples was an acceptable, and to a significant extent manageable, setback in a much widerreaching political game.

The excavations at Herculaneum and Pompeii were also valuable because they created an immediate and emotionally loaded link between Charles and Ferdinand, descendants of a Franco-Spanish dynasty, and the Italian landscape over which they ruled. Through his ownership of and investment in the excavations, Charles of Bourbon signaled his commitment to a Neapolitan heritage. His decision to leave behind even his own cameo ring, a discovery of the excavations, on his return to Spain in 1759 was a symbolic subordination of personal aggrandizement to the concerns and property of the state, an attitude more reminiscent of the limited monarchy of England than the kind of enlightened absolutism with which Charles's regime is typically associated. ${ }^{26}$ The most successful Bourbon propaganda was that which managed to combine the demands of monarchical supremacy with an appreciation for a historic and continuing Neapolitan identity.

Paderni's letters, written after his court employment first as draftsman and then as curator of the royal museum and published in the Transactions of the Royal Society, manifest conflicting desires: on the one hand, to participate in a prestigious academic society by sharing new information and discoveries (Paderni was elected a fellow of the Royal Society in 1755), on the other, to restrict the dissemination of specific details relating to the excavations out of loyalty to the Bourbon court. "I am not at liberty to be more explicit," he writes, regarding the subject matter of the newly discovered papyri in 1754 , but promises that " $[\mathrm{w}]$ hen they are published, they shall be immediately conveyed to you." 27 Yet despite these divisive impulses, Paderni remains committed to the aims of the Bourbon court, which he furthers by drawing on the vocabulary of special proximity between present and past that he had, in a small way, helped to establish in 1740 and that had, by the 1750 s, become a characteristic feature of European encounters with Herculaneum and Pompeii.

In 1739 Paderni introduced the excavations at Herculaneum as the special project of Charles of Bourbon: "[y] ou may remember, I told you in one of my former Letters, that the King of Naples was become a Virtuoso." 28 This dismissive acknowledgment suggests at best a lack of interest, at worst a skeptical disbelief, in the sincerity and depth of Charles's antiquarian feelings. A decade and a half later, Paderni once again discusses this monarch's interest in the excavations, but in language that highlights the shift in attitude that has taken place in the intervening years:

26. George III officially surrendered the revenues of Crown lands to Parliament in 1750 . For an account of Charles of Bourbon's cameo ring, see Pietro Giovanni Guzzo, "Lanello di Carlo di Borbone, re di Napoli e di Sicilia," in Omni pede stare: Saggi architettonici e circumvesuviani in memoriam Jos de Waele, ed. Stephan T. A. M. Mols and Eric M. Moormann (Naples, 2005), 331-34.

27. "Extract of a Letter from Camillo Paderni, Keeper of the Herculaneum Museum, to Thomas Hollis, Esq; Relating to the Late Discoveries at Herculaneum," Philosophical Transactions 48 (1754): $821-25$ at 825 .

28. "Extracts of Two Letters from Sigr Camillo Paderni," Philosophical Transactions 41 (1740): $484-89$ at 484 . 
His majesty the king, my master, is always increasing his taste for matters of antiquity, which he loves with the zeal of the most passionate antiquary. [...] Fortune seconds his endeavours, and makes him at this day one of the happiest virtuosi in Europe; and we may say, that he hath no ocasion [sic] to take pains to seek for good fortune, for she always attends him. [...]

[...] we may conclude, that they have formerly dug here, but irregularly; fortune having a mind to reserve the best part for the king my master. ${ }^{29}$

Paderni not only promotes Charles as a passionate virtuoso, but does so by appropriating the language of fortunate, destined encounter between ancient remains and modern observer that was characteristic of some of the earliest European accounts of Herculaneum. Paderni's language of fortunate discovery straddles the divide between enlightened cultural supremacy and providentially sanctioned absolutism, supporting Charles's claim to both. By using the language of contemporary European visitors in a new context to express Charles's supremacy, Paderni implies that the aims of these visitors and those of the Bourbon court are complementary rather than oppositional, elements in the same discourse of privileged and fated encounter between present and past.

In his roles as curator and engraver for the Bourbon court, Paderni had many opportunities to communicate the ideology of this institution to a European audience. The Herculaneum Museum at Portici, housed in one of Charles's royal palaces, displayed the finds of the Bourbon excavations in an environment designed to highlight the link between these ancient discoveries and royal patronage. Latin epigrams, composed by the Neapolitan antiquary Alessio Simmaco Mazzocchi, directed visitors' attention to the vital role played by the Bourbon monarchs. Winckelmann records that the legend "HERCVLEAE EXVVIAS VRBIS TRAXISSE VESEVI / EX FAVCIBVS VNA VIDEN REGIA VIS POTVIT" (See how royal authority alone is able to draw out from the abyss of Vesuvius those things of which the city of Herculaneum was once despoiled) was inscribed above the museum's entrance. ${ }^{30}$ In the publications issued by the courtsanctioned Reale Accademia Ercolanese, Charles was also identified as the inspiration and guiding force of the excavations. The engraved frontispiece of volume 1 of the Antichità di Ercolano displays a portrait of Charles surrounded by the tools and products of the excavations, as well as weapons and representations of his military successes (fig. 1). As the artist responsible for the design of this engraving, and as guardian of the politicized collections of the Herculaneum Museum, Paderni was ideally placed to pursue a synoptic approach to the dissemination of a message of Bourbon supremacy in a language amenable to the intellectual and political elites of Europe.

29. "An Account of the late Discoveries of Antiquities at Herculaneum, \&c. in Two Letters from Camillo Paderni, Keeper of the Musaeum Herculanei, to Thomas Hollis, Esq; Translated from the Italian by Robert Watson, M.D. F.R.S.", Philosophical Transactions 49 (1755): 490-508 at 490, 494.

30. Johann Joachim Winckelmann, Letter and Report on the Discoveries at Herculaneum, ed. and trans. Carol C. Mattusch (Los Angeles, 2011), 135-36. 
The modern-day Latin inscriptions at the Portici museum and the frontispiece of the Antichità can be seen as attempts to accord to the political sentiments of the present day something of the memorial grandeur more commonly associated with the ancient past. Mazzocchi's dedicatory inscriptions imitate those unearthed in the buried cities, several of which celebrate the role of the city's political benefactors and statesmen, such as Marcus Nonius Balbus. One of the most important of these is reproduced at the bottom right of Paderni's frontispiece (M. NONIO. M. F. BALBO. PR. PRO. COS. HERCVLANENSES), where it serves as a symbolic example of the importance of Charles's antiquarian pursuits: the inscription was celebrated as the first find that confirmed the identity of the excavated city as Herculaneum. The original of this inscription was also displayed in the Herculaneum Museum on the pedestal of Balbus's equestrian statue, itself an important artifact given the relatively few classical equestrian statues that had been unearthed at the time. Images of this statue and its counterpart (which depicted the younger Balbus's father) were among the most widely disseminated from the Bourbon excavations. The statues were re-created in biscuit ware by the Real Fabbrica della Porcellana, and the statue of the son was illustrated in the engraved series title page of the first volume of the Antichita di Ercolano. ${ }^{31}$ The ideological value of both the statues themselves and the inscriptions associated with them was not limited to their antiquarian importance. As a "ruling" dynasty and source of public good, the Balbi were obvious sources of positive comparison with the contemporary monarchy, and the prominent display and dissemination of these images invited European observers to identify Charles not only as a restorer of the ancient past but also as the modern counterpart of a virtuous ancient governor. Words like restorer (instaurator-used in another of Mazzocchi's inscriptions) take on a new significance when understood in relation to these rhetorical devices. Charles not only rediscovers lost art and learning but also re-creates the golden age of the early empire, with its benevolent absolutism and imperial patronage, in the present day.

The political message of the Bourbon court, which is exemplified but by no means limited to the works of Paderni, colored all aspects of the excavations of Herculaneum and Pompeii throughout the eighteenth century. Often, the Bourbons' political aims are seen as being in direct and obvious conflict with those of European visitors, with the two groups drawing on radically different ideology and cultural vocabulary. Yet Paderni, who operated in both worlds, was able to mitigate this conflict by appropriating the cultural language used by European visitors to the ancient cities and, with just a few tweaks of application and emphasis, making it support a message of enlightened absolutism. The language of destined encounter and of reanimation of the ancient past is utilized, by Paderni, in a new context, where it allows him to propagate a public and political message in support of Charles's rule, but also to effect a personal, verbal reconciliation (at least a partial one) between his concerns as an employee of the Bourbon court and as a member of a Europe-wide community of virtuosi and connoisseurs. ${ }^{32}$

31. Stefania Adamo Muscettola, "Nuove letture borboniche: i Nonii Balbi ed il Foro di Ercolano," Prospettiva 28 (1982): 2-16.

32. Paderni's attempts to gain membership of the cosmopolitan republic of letters were never fully successful, however. Winckelmann dismissed his methods and abilities despite relying on him for access 


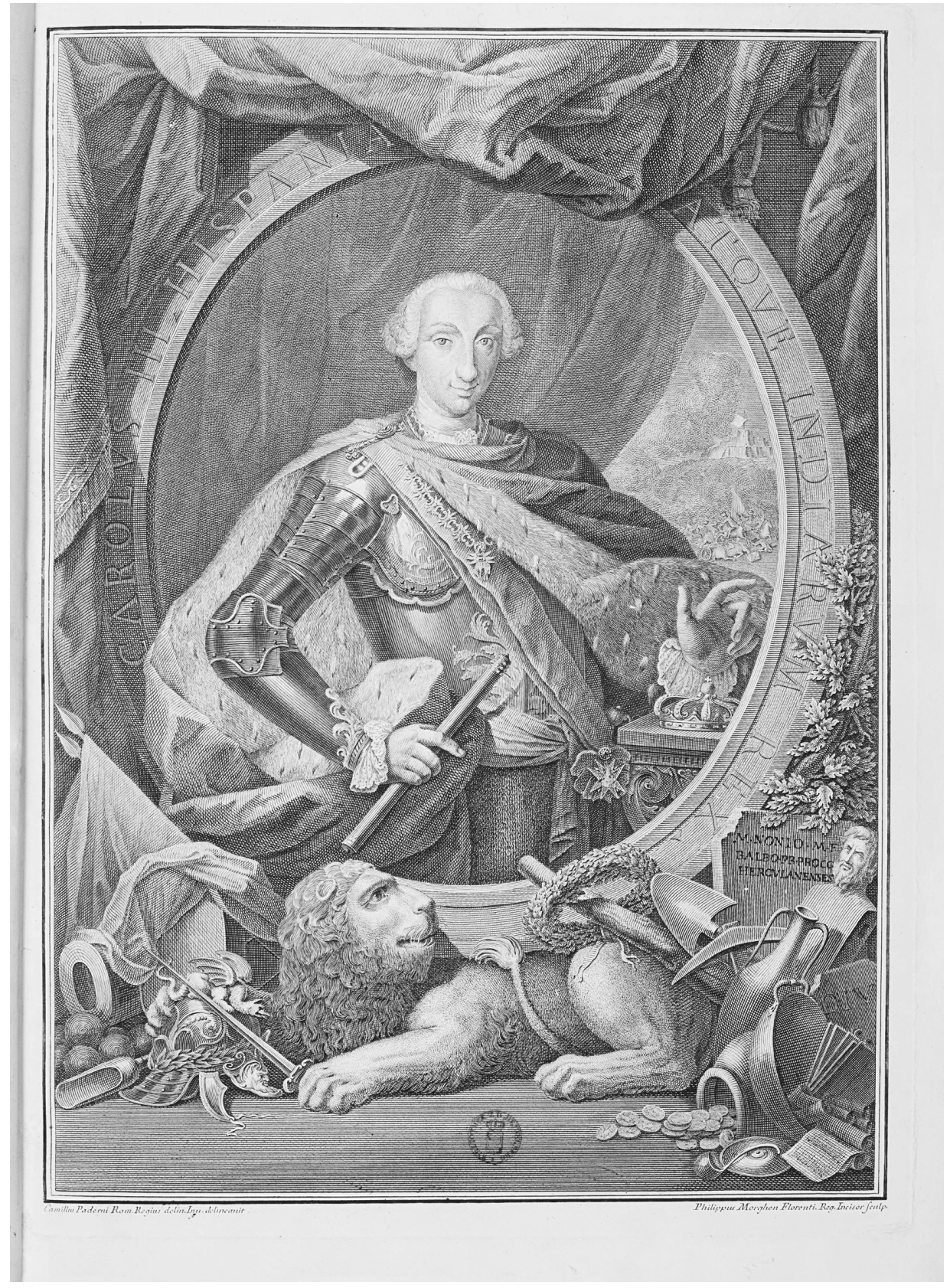

FIGURE 1. Frontispiece portrait from Le antichità di Ercolano esposte, vol. 1, Le pitture antiche d'Ercolano e contorni (Naples, 1757). Heidelberg University Library. 


\section{Winckelmann, Goethe, and the Beauty of the Everyday}

Even before Johann Joachim Winckelmann had been to Italy or visited Herculaneum and Pompeii, the relationship between ancient and modern dominated his life and work. In Reflections on the Imitation of Greek Works in Painting and Sculpture, published in 1755 and translated into English in 1765, he argues that modern artists can only hope to attain the highest standards of beauty through the imitation of those ancient Greek masterpieces that are expressions and manifestations of a society uniquely attuned to the beautiful ideal.33 "Imitation" and "ideal" are both ambiguous concepts in Winckelmann's work: the former seems to combine physical replication with ideological revival; the latter gestures toward a timeless standard but also the values and achievements of a particular historical period. These terms were ripe for exploration in the environment of the eighteenth-century Neapolitan excavations where, as we have already seen, imitation of the ancient world often involved a deeper identification and more essential connection, and where the remnants of a historical past were accorded a timeless significance. Winckelmann's Letter on the Herculanean Discoveries (1762) and Report of the Latest Discoveries at Herculaneum (1764) are famous for their disparagement of the Bourbon excavation practices and for their contempt for the errors, distortions, and myopias of previous scholars. These accounts also reveal, however, Winckelmann's struggle with some of the tensions inherent in his own theories that, brought to the fore by his encounter with these sites, are nevertheless not fully resolved.

The aesthetic impact of the excavations at Herculaneum and Pompeii, which publications like Winckelmann's helped to further, is most clearly seen in those objects of everyday use - jewelry, clothing, interior decorations, furniture-that met the late eighteenth-century demand for all things "à la grecque" or, as one contemporary reworked the phrase, "à Erculanum." 34 Might this association of a classical aesthetic with minor objects of everyday use indicate, as Ferdinando Bologna has suggested, something more than a popular taste for Etruscan borders and flowing lines? Might it be part of the establishment of a new standard of art, one that was at once universal and timely? Bologna argues that the particular aesthetic inspired by the Bourbon excavations both looks back to and extends the early eighteenth-century preoccupation with

to the excavations and their finds. William Hamilton described him as "that wicked and ignorant rascal" in a letter to Charles Townley, January 22, 1803 (British Museum, Townley papers), quoted in Ian Jenkins, “'Contemporary minds': Sir William Hamilton's Affair with Antiquity, in Vases and Volcanoes: Sir William Hamilton and His Collection, ed. Ian Jenkins and Kim Sloan (London, 1996), 40-64 at 44.

33. Although Winckelmann wrote his Reflections (Gedanken über die Nachahmung der griechischen Werke in Malerei und Bildhauerkunst) before he visited Herculaneum and Pompeii, the work was inspired by three statues (Winckelmann calls them vestals; they are now known as the Herculaneum Women) in the royal antiquities collection at Dresden that were discovered by the workmen of the Prince d'Elboeuf, probably in 1711, among the earliest finds to be unearthed at Herculaneum.

34. Ferdinando Galiani to Bernardo Tanucci, 1767. Quoted in Ferdinando Bologna, "The Rediscovery of Herculaneum and Pompeii in the Artistic Culture of Europe in the Eighteenth Century," in Rediscovering Pompeii: Exhibition by IBM-ITALIA, New York City, IBM Gallery of Science and Art, 12 July-September 15, 1990 (Rome, 1990), 79-91 at 79. 
"functionalism." 35 The belief that beauty and utility are inextricably linked encouraged the purgation of baroque ornament and the championing of strength and moderation over delicacy and excess. This theory also suggests a possible solution to the tensions inherent in Winckelmann's definition of ideal beauty. An aesthetic standard founded on utility is eminently responsive to the needs and conditions of particular societies and cultures: it is contemporary and pragmatic rather than traditional or theoretical. At the same time, such a standard represents a universal ideal that can always be applied, independent of the vagaries of fashion, and is unaffected by most changes of society or culture. Understood in this way, a study of the objects unearthed at Herculaneum and Pompeii, especially one conducted in the immediate environment of the excavations, appears to offer an unprecedented opportunity for Winckelmann to refine his theory of the aesthetic ideal. No other ancient site offered the prospect of combining the study of ancient art with historical enquiry into the everyday conditions in which it was created. Winckelmann takes full advantage of this occasion, combining his accounts of the beauties unearthed in these cities with miniature dissertations on ancient Roman window coverings, technologies of writing, and children's games. Herculaneum and Pompeii offered the interested visitor large collections of everyday objects, buried since the first century CE, that could also be used to illustrate ancient art's functionalist aesthetic. It is the official publication of descriptions and reproductions of these objects, Winckelmann suggests in his Report, that the people of Europe anticipate most eagerly. ${ }^{6}$ Finally, and most importantly, the vivid proximity between the ancient and the contemporary that was, for so many, characteristic of the environment of these excavations created a potential opening for Winckelmann and others to identify a shared aesthetic ideal. Through the identification of common elements that unite the ancient citizens of the buried cities with the modern inhabitants of Naples, a universal standard of beauty might be found, not so much in the expression and drapery of ancient statues, but forged by the enduring conditions of the everyday.

In his early Reflections on the Imitation of Greek Works Winckelmann argues that the ancient Greeks were able to obtain the "ideal riches" of beauty more easily than moderns because they encountered this standard "daily" and because it was embedded in their culture and way of life. 37 In his Letter and Report on the excavations at Herculaneum and Pompeii, Winckelmann shows no tendency to celebrate the modern environment of Naples as possessing a similar standard of assimilated beauty. Throughout these two works Winckelmann identifies other points of comparison between the artifacts discovered in these buried cities and modern European customs. Soles for shoes made from rope, in sizes for children and adults, for instance, "are just

35. Bologna, "Rediscovery of Herculaneum and Pompeii," 81.

36. Winckelmann, Letter and Report on the Discoveries at Herculaneum, 199.

37. Winckelmann, "On the Imitation of the Painting and Sculpture of the Greeks," in Reflections on the Painting and Sculpture of the Greeks: with Instructions for the Connoisseur, and an Essay on Grace in Works of Art, trans. Henry Fuseli (London, 1765), 18. 
like the soles people from Lica tie under the foot even today." 38 However, past and present are not, for Winckelmann, united by any common aesthetic ideal. In another example, the colloquial or obscene gestures made by figures in ancient bronzes are explained by an appeal to modern Neapolitan customs. This explanatory power, however, instead of suggesting some special communication or inheritance uniting the ancient and the modern inhabitants of this region, resolves itself, in Winckelmann's account, into an accusation of primitivism and superstition directed at the modern Neapolitans. Winckelmann describes the discovery of a number of bronze Priapi:

These were ancient amulets or pendants, which one wore against curses, against the evil eye, and against sorcery. This ridiculous and shameful superstition survives even today among the common folk in Naples. They let me see some examples of the Priapus that they wear around the wrist or around the neck. In particular, there is a silver half-moon worn on the arm, which the commoners call luna prezzura, that is, the pointed moon, which is supposed to prevent epilepsy. It must be made from alms one has gathered oneself, and one takes it to the priest for a blessing, an abuse that is known about and tolerated. Perhaps the many silver halfmoons in the museum served the same purpose. 39

The habits of the present can inform our study of the past, but this does not mean that the two are united by any shared values or ideals. Winckelmann instead comes close here, despite his own Catholic affiliation, to the traditional Protestant critique that extrapolates, from the continuance of ancient superstitious practices in present-day Italy, an argument for Catholicism's development from an earlier pagan tradition.

Yet despite his unwillingness to countenance a meaningful connection between the ancient and modern worlds at Herculaneum and Pompeii, Winckelmann is still drawn, in his examination of the Bourbon collections, to the implements and utensils of everyday use. These objects inspire Winckelmann's only reflection, in either his Letter or his Report, on the nature of ideal beauty and its ambiguous situation as a historically contingent cultural standard and as a timeless verity. At the end of the section of his Letter detailing objects of necessity, luxury, adornment, and entertainment, Winckelmann reflects on their aesthetic value:

Consideration of these utensils and especially the vessels should focus on their elegance, which all our modern artists cannot match. Their forms are basically built upon the principles of good taste and resemble a beautiful young man who develops grace in his bearing effortlessly and unconsciously. This grace in the vessels reaches even to its handles. The imitation of that grace could usher in an entirely different taste, one that could lead us away from artifice and toward nature, wherein real art 
can then be exhibited. [... ] What is easy [on the eyes] pleases us for its intelligibility, in contrast to the contrived, which, like exaggerated praise, offends us because we believe that we cannot live up to it. Since nature illuminates our way, in view of the costs (usually the natural is cheaper than the artificial), sensation and reflection should guide us toward the beautiful simplicity of the ancients. But they adhered to what was once understood to be beautiful, for beauty is simply one thing, and like their clothing, it did not change. We, on the other hand, cannot or do not like to lay down rules about such things as beauty, so we make foolish imitations, at one moment building something, and, at the next, like children, tearing it down. 40

The ideal of Greek art is most visible in the ordinary household paterae found at Herculaneum and Pompeii, the graceful forms of which ought to inspire a revival of this ancient standard. Their beauty is in important ways connected with the functionalist aesthetic: natural rather than artificial, simple rather than contrived, and closely aligned with such pragmatic concerns as cost. The beauty of the ancient Greeks may be ideal, but we should not understand by this that it was in any way theoretical or abstracted. Rather, its permanence stems from its constant applicability to the concerns of the human condition. The ideal of beauty to which Winckelmann gestures here is both historic and timeless, and it unites these seemingly contradictory elements in the beauty of the everyday. This ideal unity is not one, however, that Winckelmann is able to see as he looks from the manifestations of the ancient past found at Herculaneum and Pompeii to the contemporary world of eighteenth-century Naples.

Johann Wolfgang von Goethe, himself hugely influenced by Winckelmann, traveled to Herculaneum and Pompeii in 1787. In his Italian Journey he expresses his delight with the Neapolitan landscape, although, perhaps in common with Winckelmann, he sometimes struggles to reconcile the sensual pleasures of modern Neapoli$\tan$ life with the feelings inspired by the remains of classical antiquity. Despite these tensions, Goethe's account of Naples appreciates, much more than does Winckelmann's, the value of the modern city, especially when viewed as a reflection of its Roman past. Goethe celebrates the life led by Naples's underclass, the lazzaroni, as functional, utilitarian, and without waste, motivated by the pursuit of pleasure and enjoyment. These are the same qualities that, drawing once again on the functionalist aesthetic, Goethe sees in the decorated objects unearthed from Herculaneum and Pompeii that speak to him of the beauty of ancient art. On a visit to the Portici museum, Goethe is struck by the quantity of ancient artifacts:

Those little houses and rooms in Pompeii now seemed to me both more cramped and more spacious: more cramped, because I pictured them crowded with all these worthy objects, more spacious, because these same objects were not there merely out of necessity, but were so very

40. Ibid., 116. 
ingeniously and charmingly decorated and enlivened by visual art that they delight and expand the mind more than the most spacious interior could.

For example, we saw a magnificently shaped bucket, with the most elegant upper rim; on closer inspection, this rim can be raised up from two sides, the combined semicircle is grasped as a handle and the vessel can be carried most comfortably. The lamps are decorated with as many masks and scrolls as they have wicks, so that each flame illuminates a genuinely artistic creation. ${ }^{41}$

The combination of the functional and the artistic, of utility and pleasure, and in particular that absence of superfluity that is ensured when the beautiful and the useful are shown to unite together (the bucket's elegant rim is also a comfortable handle; each wick reveals a work of art at the same time as it provides general illumination) lies at the heart of Goethe's definition of ancient beauty but also his characterization of modern Neapolitan society. He comments on the lack of waste-even the residual heat from a blacksmith's fire and the stalks of green vegetables are put to use-and the industriousness that, because of the warm climate and fertile soil, can be directed toward present enjoyment rather than future necessity..$^{42}$ The humble people combine work and play, and "work not merely to live, but to enjoy." 43 If this means that they achieve less technical proficiency than other nations (Goethe remarks on their comparative backwardness in manufacture, erudition, and artistic skill), then they are in good company. It is among the antiquities of the Portici museum, Goethe asserts, that "one really can see how far advanced the ancient world was in its joyful sense of art, even if it remained far behind us in strict technical proficiency." 44

At the conclusion of his visit to Pompeii-where he observed, in particular, the remains of wall paintings-Goethe articulates most clearly the sensibility that he sees uniting the ancient and modern societies of this region, a sensibility that allows him to rework and extend Winckelmann's theory of the beautiful ideal. 45 Goethe has already commented on the modern habitations surrounding this ancient site:

41. Johann Wolfgang von Goethe, Italian Journey, trans. Robert R. Heitner, ed. Thomas P. Saine and Jeffrey L. Sammons, vol. 6 in Goethe's Collected Works (New York, 1989), 173.

42. Goethe's account of the lazzaroni is unusual among those of British, French, and German visitors for its largely positive and celebratory tone, but it nevertheless draws on the same climatic theory that they used to characterize the Neapolitan people as lazy and luxurious. For an account of this practice and the quasi-colonial nature of northern European encounters with Naples in the eighteenth century, see Melissa Calaresu, "Looking for Virgil's Tomb: The End of the Grand Tour and the Cosmopolitan Ideal in Europe," in Voyages and Visions: Towards a Cultural History of Travel, ed. Jaś Elsner and Joan-Pau Rubiés (London, 1999), 138-61.

43. Goethe, Italian Journey, 266.

44. Ibid., 270.

45. Thorsten Fitzon suggests that Goethe accepted the arabesques and grotesques that surrounded many of the wall paintings at Pompeii, and that might initially have offended his neoclassical sensibilities, because they served a useful purpose as framing devices, emphasizing the degree to which the functionalist aesthetic informed Goethe's reception of these sites; "A Tamed 'desire for images': Goethe's Repeated Approaches to Pompeii," in Pompeii in the Public Imagination from its Recovery to Today, ed. Shelley Hales and Joanna Paul (Oxford, 2011), 15-33. 
On the outskirts of the city I was struck again by the little houses, which look like perfect imitations of those in Pompeii. We asked permission to enter one of them and found it very neatly furnished. Nicely woven cane chairs, a chest of drawers gilded all over, decorated with colorful flowers, and varnished-evidence that this region, after so many centuries and innumerable changes, still invests its inhabitants with similar manners and customs, inclinations and fancies. 46

The similarities between the modern Neapolitans and their ancient counterparts is not, here, an indication of the primitive backwardness of the former culture. Instead Goethe is able to decipher a "message descended from remotest antiquity" even in the "coarseness of everyday life." 47 The modern Neapolitans are, in a full and complex sense, living history: they not only participate in the habits and conditions of the past but also animate and update them, thereby hinting at the possibility of some timeless and universal ideal. $4^{8}$ Visitors to Herculaneum and Pompeii typically commented on the special proximity, even uneasy slippage, between ancient and modern that these sites seemed to promote, but only a few individuals saw in this tendency a new way of thinking about art, beauty, and the ideal.

\section{Sir William Hamilton and the History of the Earth}

The day he first arrived in Naples as British envoy to the Neapolitan court, William Hamilton began an observation of Mount Vesuvius that was to occupy him until he left Italy in $1800.49 \mathrm{He}$ investigated the volcanic origins of the landscape of Southern Italy with scrupulous detail: he observed the mountain daily, made special visits to neighboring volcanic islands, and collected rock and soil samples. In 1794 Hamilton recorded that he had climbed to the highest point of Vesuvius sixty-eight times, a perilous undertaking during the volcano's many periods of intense activity. 50 Only to the collection and study of antiquities did Hamilton dedicate similar effort, time, and money.

46. Goethe, Italian Journey, 163.

47. Alain Schnapp paraphrases the views of the early nineteenth-century antiquarian Andrea de Jorio in "Antiquarian Studies in Naples at the End of the Eighteenth Century: From Comparative Archaeology to Comparative Religion," in Naples in the Eighteenth Century, ed. Imbruglia, 154-66 at 165.

48. The connections that Goethe draws between contemporary Naples and the ancient world recall, but also fundamentally differ from, those made by contemporary Neapolitan historians. While Goethe looks to the region's Roman past for valuable historical exempla, writers such as Giovanni Donato Rogadei and Giuseppe Maria Galanti turned to the pre-Roman, Sabine history for parallels that justified and illuminated Naples's contemporary political emancipation. See Melissa Calaresu, "Images of Ancient Rome in Late Eighteenth-Century Neapolitan Historiography," Journal of the History of Ideas 58, no. 4 (1997): 641-61.

49. “Two Letters from the Hon. William Hamilton, His Majesty's Envoy Extraordinary at Naples, to the Earl of Morton, President of the Royal Society, containing an Account of the last Eruption of Mount Vesuvius," Philosophical Transactions 57 (1767): 192-200 at 192.

50. "An Account of the Late Eruption of Mount Vesuvius, in a Letter from the Right Honourable Sir William Hamilton, K.B.F.R.S., to Sir Joseph Banks, Bart, P.R.S.," Philosophical Transactions 85 (1795): 73-116 at 94-95. 
The decision to combine antiquarian study and natural history was not a new or unusual choice for an individual residing in the environs of Naples in the early modern period. At least as far back as the major eruption of 1538, two hundred years before the excavation of Herculaneum and Pompeii, scholars had combined surveys of the landscape with accounts of the major ruins to be found in the area, motivated in part by the imminent threat the volatility of the former apparently posed to the latter. ${ }^{11}$ In Hamilton's letters to the Royal Society detailing his volcanic observations (a collection of which were later published in the lavishly illustrated Campi Phlegraei in 1776), he often illustrates natural history with references to ancient sources and occasionally interrupts it with observations of classical ruins. Hamilton differs from earlier examiners of the Vesuvian landscape, however, in the uses to which he puts his Roman sources and the significance that he attributes to his digressions on antiquarian matters. Appeals to classical writers as authorities are extremely rare in Hamilton's work, and he almost never engages with the theories put forward by ancient writers to explain volcanic activity. Despite a European reputation as the "modern Pliny," Hamilton did not, on the whole, view ancient writings on volcanoes as sources for imitation..$^{2}$ Sean Cocco notes that observers of the seventeenth-century eruption of Vesuvius had a tendency to fashion their narratives "in imitation of the canonical classical description," a practice that involved not only repeating the descriptive features of Pliny's famous letters (the cloud of smoke emerging from the mountain resembles a pine tree, just as it does in Pliny's account) but even deliberately replicating the actions and behavior of Roman observers. Giulio Braccini, for example, declares that he read Pliny the Younger during the eruption, thereby appealing to a classical source in preference to personal observation and also imitating the actions of Pliny himself, whose decision to read during the eruption of $79 \mathrm{CE}$ can be interpreted as an act of stoic self-command designed to calm the household and reassure his mother.53 When Hamilton appeals to Pliny in the course of his volcanic writings, even repeating the same simile of the pine tree, his intentions are very different. Hamilton uses classical texts, but not as sources of authority or as exemplary works. Instead the remains of the ancient world, physical and literary, become useful markers in an immeasurably larger history: that of the earth itself. 54

Human history, in Hamilton's letters, is dwarfed by nature, both by the magnitude of its operations and the imperceptible slowness of its change. Hamilton's Pan-

51. Sean Cocco, "Natural Marvels and Ancient Ruins: Volcanism and the Recovery of Antiquity in Early Modern Naples," in Antiquity Recovered, 15-35.

52. "I frequently receive letters from my fellow Volcanistes, who are pleased to call me Le Pline moderne du Vesuve," British Library, Add. MS. 34048, fol. 26, quoted in John Thackray, "“The Modern Pliny': Hamilton and Vesuvius," in Vases and Volcanoes, 65-74 at 68.

53. Cocco, "Natural Marvels and Ancient Ruins," 28. Hamilton quotes from Braccini's account of the 1631 eruption of Vesuvius in his letter to the Royal Society of October 1770.

54. Hamilton's apprehension of the earth's vast prehistory was shared by several of his Italian contemporaries, with whom he worked closely during his volcanic studies. His guide on his visit to Etna, Canon Giuseppe Recupero, noted that the alternating layers of lava and weathered topsoil uncovered during the excavation of a well on the lower slopes traced a period of at least 14,0oo years. Martin J. S. Rudwick, Bursting the Limits of Time: The Reconstruction of Geohistory in the Age of Revolution (Chicago, 2005), 120-22. 
glossian faith in the benevolent purposes of volcanoes and earthquakes is justified by the argument that nature operates "on a scale perhaps much too great and extensive for our weak and limited comprehension." 55 Human endeavor cannot begin to contend with the vastness of nature's transformations. Describing the impact of the 1794 eruption, Hamilton asserts that " $\mathrm{t}]$ en thousand men, in as many years, could not, surely, make such an alteration on the face of Vesuvius, as has been made by nature in the short space of five hours." 56 The destruction of Herculaneum and Pompeii, when viewed in relation to "the great scale of nature," are merely "partial misfortunes," the consequences of a "chance or ill fate" that happened to situate them "in the line of one of [nature's] operations." 57 The significance of this disaster of the ancient world, and by extension its huge importance for modern excavators and observers, dwindle in the face of an alternative history of vastly greater scope.

In the opening remarks of his Campi Phlegraei, Hamilton includes an extract from a report by Horace-Bénédict de Saussure on the nature of the soil in and around Rome. Unlike at Herculaneum and Pompeii, at Rome all ancient monuments, and by extension all the political revolutions of Roman history, are located in the present geological moment. The city rests upon a soil that testifies to the great physical revolutions that took place before its founding. Just outside Rome Saussure observes a small hill with an exposed cross section that displays clearly demarcated layers of different soils and rocks. At the top of this hill are the ruins of a building "whose mosaick pavement ascertain'd its antiquity," but this surface monument cannot help Saussure to date the lower deposits, which indicate an inaccessibly ancient history lying beyond even the ancient Roman past:

It wou'd certainly have been very interesting to have found $[$ sic $]$ in the lower strata some monument, that cou'd point out the time in which they were formed. It is well known that this Tufa is produced by fire; that those pebbles have been rounded by water, and that this hill then has been formed by the alternate operations of fire and water: but who will tell us, when, and at what intervals? 58

The incommensurability of human history and the prehistory of the natural world in this landscape stands in contrast to the area around Naples, where the remains of ancient civilizations are located within the strata observed by natural historians. Pompeii and Herculaneum are covered by layers of soil and rock testifying to a long series

55. "Some Particulars of the Present State of Mount Vesuvius; with the Account of a Journey into the Province of Abruzzo, and a Voyage to the Island of Ponza. In a Letter from Sir William Hamilton, K.B.F.R.S. and A.S. to Sir Joseph Banks, Bart. P.R.S."' Philosophical Transactions 76 (1786): 365-81 at 380.

56. "An Account of the Late Eruption of Mount Vesuvius," Philosophical Transactions 85 (1795): $73-116$ at 96.

57. William Hamilton, Campi Phlegraei: Observations on the Volcanos of the Two Sicilies as they have been Communicated to the Royal Society (Naples, 1776), 3-4.

58. Ibid., 10. 
of eruptions, and layers of pumice and burnt matter are also discoverable under the foundations of these towns. "I do not pretend to say that a just estimate can be formed of the great age of volcanos from this observation," Hamilton writes in 1770, "but some sort of calculation might be made." 59 Human history allows Hamilton to glimpse the vast chronology that governs the transformations of the natural world. In his account of his visit to Etna, Hamilton argues that all Sicily's mountains are the results of volcanic activity, with their differing degrees of lushness and fertility indicating their different ages: "those (which I imagine to be the most modern) are covered with ashes only; others of an older date, with small plants and herbs, and the most antient, with the largest timber-trees I ever saw; but I believe the latter are so very ancient, as to be far out of the reach of history." The middle region of Etna "was famous for its timber in the time of the Tyrants of Syracusa," and this fact gives some indication of "the great age of this respectable volcano." 60 The history of the ancient world may be dwarfed into insignificance by the vast operations of nature, but ancient history acts as a valuable foil to a much more extensive history of geological change, one that Hamilton cannot measure but the temporal scope of which he was just able to perceive.

The slowness of natural change, Hamilton argues, places it beyond the limits of our observation and almost of our understanding, despite the timely assistance provided by Roman history. " $\mathrm{N}]$ ature acts slowly, it is difficult to catch her in the fact," and for Hamilton, who relied upon empirical observation in order to formulate his theories, this posed a significant challenge. A partial solution to this difficulty is suggested by Hamilton's often-repeated assurance that "[n]ature, though varied, is certainly in general uniform in her operations." 61 This uniformity provides Hamilton with a much larger field of enquiry. Instead of limiting himself to an account of the actions of Vesuvius that he had himself observed-an account which, at a mere thirtyfive years duration, would only represent a tiny fraction of the life cycle of that mountain-Hamilton is able to expand his enquiries to encompass the whole of the Neapolitan caldera, as well as other sites in Southern Italy. Ultimately, the comparability of different volcanic areas offers the possibility of an integrated theory of the earth that might combine Hamilton's own observations with those made by other naturalists in other parts of the globe. It is not necessary to dig down into the earth in order to find the traces of nature's past. Instead, this past is spread out like a map on the surface of the world, where hills (such as the Monte Nuovo-thrown up by the eruption of 1538), huge mountains, and volcanic plains from which the volcanic cones have been eroded all testify to the full scope of natural history.

If the uniform operations of nature allow Hamilton to look beyond the immediate environs of Vesuvius for evidence of its history and probable future development,

59. "Remarks upon the Nature of the Soil of Naples, and its Neighbourhood; in a Letter from the Honourable William Hamilton, His Majesty's Envoy Extraordinary at Naples, to Mathew Maty, M.D. Sec. R.S.," Philosophical Transactions 61 (1771): 1-47 at 6.

6o. "An Account of a Journey to Mount Etna, in a Letter from the Honourable William Hamilton, His Majesty's Envoy Extraordinary at Naples, to Mathew Maty, M.D. Sec. R.S.," Philosophical Transactions 60 (1770): 1-19 at 7, 9 .

61. "Remarks upon the Nature of the Soil of Naples," 2. 
then another set of evidence also becomes available to him. Hamilton can expand his enquiries back in time as well as in space, making use of historical reports of eruptions as if they were contemporary eyewitness sources. Throughout his writing on Vesuvius, Hamilton supports and illustrates his findings with comparable observations found in ancient and modern reports. Pliny's pine tree is invoked, as are his accounts of lightning and midday darkness. Hamilton appeals to descriptions of the eruptions of 1538 and 1631 as usefully corroborating his own observations of volcanic phenomena. This tendency in Hamilton's writing culminates, in 1794, with an explicit acknowledgment of the comparability of ancient, modern, and contemporary volcanic activity:

All great eruptions of volcanoes must naturally produce nearly the same phaenomena. [...] The classical accounts of the eruption of Vesuvius, which destroyed the towns of Herculaneum and Pompeii, and many of the existing printed accounts of its great eruption in 1631 (although the latter are mixed with puerilities) might pass for an account of the late eruption by only changing the date. ${ }^{62}$

The equivalency of the ancient and modern eruptions invites us to look again at Hamilton's combination of classical sources and contemporary observations in his writings on natural history. Antiquarianism and the study of volcanoes are usefully illustrative of one another in Hamilton's earlier writings: he collects samples of rock from the theater at Herculaneum, for example, and a few pages earlier compares the shape of volcanic craters to ancient theaters and amphitheaters. ${ }^{63}$ However, his assumption of comparability also indicates some deeper association, one that finds expression in Hamilton's reflections on the modern dangers faced by the inhabitants of the Kingdom of Naples. "Had the eruption lasted an hour longer," writes Hamilton of the eruption in 1779, "Ottaiano must have remained exactly in the state of Pompeia, which was buried under the ashes of Vesuvius just 1700 years ago, with most of its inhabitants, whose bones are to this day frequently found under arches and in the cellars of the houses of that ancient city." ${ }^{4}$ During the eruption of 1794 he apprehends "Naples to be in some danger of being buried under the ashes of the volcano, just as the towns of Herculaneum and Pompeii were in the year $79 . " 65$ The ancient and modern cities of the Neapolitan region are separated by "just" 1,700 years, a mere heartbeat in the scale of the great transformations of the natural world, and this proximity is reinforced by their experience of a common nature, uniform in all its actions and operations, whose impact on humanity has the potential to be the same in the years of British-Italian diplomacy as it was in the years of imperial Rome.

62. "An Account of the Late Eruption of Mount Vesuvius," Philosophical Transactions 85 (1795): $73-116$ at $73-74$

63. "Remarks upon the Nature of the Soil of Naples," 12,15

64. "An Account of an Eruption of Mount Vesuvius, which happened in August, 1779. In a Letter from Sir William Hamilton, K.B.F.R.S., to Joseph Banks, Esq. P.R.S.," Philosophical Transactions 70 (1780): $42-84$ at 71 .

65. "An Account of the Late Eruption of Mount Vesuvius," 92. 
Hamilton's reflections on Vesuvius and the volcanic activity, past and present, of Southern Italy were distributed in a variety of media during his lifetime. Letters to private correspondents became oral (and frequently visual) presentations to the Royal Society, which in turn were published in the Philosophical Transactions and finally collected in Hamilton's own lavish volume: Campi Phlegraei. This elite and expensive publication may represent the culmination of Hamilton's own wishes for his volcanic observations, but its impact should be considered alongside the reproduction of these same observations in unsanctioned, cheap, and accessible travel guides and reference works. ${ }^{66}$ Many of Hamilton's contemporary readers would have encountered his apprehension of the common fate that could overwhelm the modern settlements of the Kingdom of Naples as it did the ancient towns of Herculaneum and Pompeii in publications that recalled the travel journals of other visitors such as James Russel, Robert Gray, Hester Lynch Piozzi, or Mariana Starke, many of whom, as we have already seen, recorded feelings of peculiarly intense connection between the dead past and the living present in the environment of these ruins. It is not clear from Hamilton's writings whether his susceptibility to feelings of uncanny proximity between present and past helped to shape his volcanic theory, or whether his understanding of volcanoes inspired his reflections on the shared experience of the ancient and modern worlds. Such questions of influence are always difficult to determine, and the answer is likely to be more complex than any purely linear relationship. What is significant, however, is that when Hamilton wished to reflect on the common dangers that afflicted both the ancient and modern inhabitants of the campi phlegraei, he did so in the same language, using the same phrases and applying the same ideas as many others who encountered the ruins of Herculaneum and Pompeii over the course of the eighteenth century. The historian of science Martin Rudwick has suggested that universalist geotheories, like Hamilton's, are implicitly ahistorical because they emphasize explanations for natural phenomena that are "valid at all times and in all places." 67 Despite the importance of Herculaneum and Pompeii as sources of knowledge about the ancient world, there is perhaps something similarly ahistorical in the impression of proximity, association, and comparability between present and past that was inspired by the excavation of these sites. If the eighteenth-century reaction to Herculaneum and Pompeii was not strictly historicized, however, it is certainly not the case that the response to these cities was purely aesthetic or nostalgic, limited to the construction of a few imitative decorations and household items.

\section{害}

The reactions of Paderni, Winckelmann, Goethe, and Hamilton to the ruins of the Kingdom of Naples are divided by idiosyncratic, personal concerns with contemporary Neapolitan politics, aesthetic theory, and natural history. However, all four were

66. Karen Woods, "Making and Circulating Knowledge through Sir William Hamilton's Campi Phlegraei," British Journal for the History of Science 39, no. 1 (2006): 67-96 at 86.

67. Rudwick, Bursting the Limits of Time, 227. 
united by a common idea: the intimate association between present and past. None of these men worked in isolation, and indeed each of them relied on transnational networks of collaboration and dissemination in order to formulate and publish their arguments. Yet despite their sometimes fraught participation in these networks of knowledge, exposure to the excavations at Herculaneum and Pompeii allowed each of them to shape ideas and arguments that differ not only from one another but also, in several cases, from most previous work conducted in their respective fields. My brief examination of the work of these four individuals has been intended to indicate the importance of the excavation of Herculaneum and Pompeii to the development of several areas of eighteenth-century thought as well as to illustrate how even a phenomenon as wide-ranging and culturally influential as the excavation of these cities could inspire personalized, experimental, and innovative individual appropriations.

C CHARLOTTE ROBERTS is a lecturer in English at University College London. Her research focuses on the historiography and historical thought of the long eighteenth century, and she is the author of Edward Gibbon and the Shape of History (2014). 
